\title{
СПОРНЫЕ ВОПРОСЫ В ТЕХНОЛОГИЯХ СОЗДАНИЯ ЛЕКАРСТВЕННЫХ СРЕДСТВ ДЛЯ ЛЕЧЕНИЯ НЕЙРОДЕГЕНЕРАТИВНЫХ ЗАБОЛЕВАНИЙ
}

\section{И.Н. Тюренков}

Научный центр инновационных лекарственных средств, Волгоградский государственный медицинский университет Минздрава России, 400087, Россия, г. Волгоград, ул. Новороссийская, 39.

Нейродегенеративные заболевания (НДЗ) - одни из наиболее распространенных и тяжелых заболеваний взрослого, и, особенно пожилого населения. Это наследственное, а чаще приобретенное заболевание, характеризуется медленно прогрессирующим течением, приводящее к гибели нейронов (холинергических, дофаминергических, ГАМК-ергических и других) и нарастающими дементными, сенсорно-моторными и психоэмоциональными расстройствами, а клиническая картина в значительной степени определяется топографией очага гибели нейронов в головном мозге. Все НДЗ - это возрастзависимые полиэтиологичные, полиморбидные, полифакторные патологии и в их основе лежат многие патофизиологические механизмы: протеинопатии (нарушение обмена $\beta$-амилоида, тау-белка и синуклеина, их конформационные изменения, сморщивание и гибель нейронов), гипоксия мозга, оксиседативный и нитрозативный стресс, митохондриальная дисфункция, глутаматная эксайтотоксичность, нейровоспаление, снижение аутофагии, синаптогенеза и др. Все эти процессы происходят под влиянием большого ряда триггеров, т.е. пусковых факторов: острых и хронических нарушений мозгового кровообращения, сахарного диабета, недостаточности половых органов, хронического стресса, хронической алкоголизации и др.

Поэтому при поиске и разработке ЛС для лечения НДЗ требуется комплексный подход, учитывающий действие препарата, по возможности, на большее число патофизиологических факторов, т.е. препаратам с поливалентным действием. Таким требованиям, по нашему мнению, в большой степени отвечают вещества с ГАМК-ергическим действием.

В докладе будут представлены данные, отражающие механизм нейропротективного действия производных ГАМК и альфапирролидона, включая и гибридные соединения, включающие другие фармакофоры (адамантановые, циклические, алифатические и ароматические заместители) при нейродегенеративных патологиях, вызванных острым и хроническим нарушениями мозгового кровообращения, СД, хроническим стрессом, хронической алкоголизацией, недостаточностью половых гормонов и другими патологиями. 